\title{
Vitamin D and Its Relationship with Obesity and Muscle
}

\author{
Cristiana Cipriani, Jessica Pepe, Sara Piemonte, Luciano Colangelo, \\ Mirella Cilli, and Salvatore Minisola \\ Department of Internal Medicine and Medical Disciplines, "Sapienza" University, Viale del Policlinico 155, 00161 Rome, Italy \\ Correspondence should be addressed to Salvatore Minisola; salvatore.minisola@fastwebnet.it
}

Received 5 January 2014; Revised 30 March 2014; Accepted 8 April 2014; Published 5 August 2014

Academic Editor: Dennis Villareal

\begin{abstract}
Copyright ( 2014 Cristiana Cipriani et al. This is an open access article distributed under the Creative Commons Attribution License, which permits unrestricted use, distribution, and reproduction in any medium, provided the original work is properly cited.

The skin synthesis of vitamin D represents the first step of a metabolic pathway whose features have been extensively studied and clarified in the last decades. In particular, the production of active and inactive forms of the hormone and the actions of the corresponding enzymes have offered new insights into the knowledge of vitamin D metabolism. Additionally, the description of the different organs and tissues expressing the vitamin D receptor and its possible functions, as well as its genetic determinants, have allowed focusing on the interrelationship between vitamin D and many physiological and pathological functions. In this context, many studies reported the association between vitamin D and adipose tissue metabolism, as well as the possible role of the hormone in obesity, weight, and fat mass distribution. Finally, many reports focused on the vitamin D-related effects on skeletal muscle, particularly on the mechanisms by which vitamin $\mathrm{D}$ could directly affect muscle mass and strength. This paper is mainly aimed to review vitamin D metabolism and its relationship with obesity and skeletal muscle function.
\end{abstract}

\section{Metabolism of Vitamin D}

It is an old knowledge that skin exposure to sunlight is the main source of vitamin $\mathrm{D}$ production $[1,2]$; in fact more than $80 \%$ of systemic vitamin $\mathrm{D}_{3}$ derives from epidermis and the other $20 \%$ is obtained through the diet from animal, cholecalciferol $\left(D_{3}\right)$, or plant, ergocalciferol $\left(D_{2}\right)$, and through drug supplementations [3].

Vitamin $\mathrm{D}_{3}$ skin production depends on a photochemical process in which epidermal 7-dehydrocholesterol (7DHC or provitamin D3) is converted to previtamin-D3 (pre-D3) by ultraviolet radiation (UVR) [4] (Figure 1). The so formed pre$\mathrm{D}_{3}$ isomerizes to $\mathrm{D}_{3}$ in a thermosensitive but noncatalytic process [5]. To prime sunlight reaction this biochemical process requires specific UVB wavelengths, between 290 and $315 \mathrm{~nm}$, present only for limited number of hours also varying with respect to latitude and season. Therefore, a number of personal and environmental factors are important to maximize the formation of pre- $\mathrm{D}_{3}$, like skin pigmentation, clothes, and sunscreen use [1]. However, prolonged exposure to sunlight does not produce toxic amounts of vitamin $\mathrm{D}_{3}$ because of the pre- $\mathrm{D}_{3}$ conversion to the biologically inactive compounds called lumisterol and tachysterol [6].

In addition to this classical way of vitamin $\mathrm{D}$ production, research over the last decade has revealed that numerous pathways for metabolism of vitamin D exist with the production of at least 40 metabolites whose role is only partially known $[3,7]$.

According to the classical pathway, to become fully active, vitamin $\mathrm{D}$ (referred to as either vitamin $\mathrm{D}_{2}$ or vitamin $\mathrm{D}_{3}$ ) must be hydroxylated on carbon 25 , forming 25-hydroxyvitamin $\mathrm{D}[25(\mathrm{OH}) \mathrm{D}]$ in the liver, and then on carbon 1 , forming 1,25 -dihydroxyvitamin $\mathrm{D}\left[1,25(\mathrm{OH})_{2} \mathrm{D}\right]$ in the kidney [8]. 25(OH)D is the major circulating metabolite of vitamin $\mathrm{D}$ because it has a half-life of 21-30 days [9], so its serum concentration is the most reliable biochemical index of vitamin repletion. $1,25(\mathrm{OH})_{2} \mathrm{D}$ is the most potent physiologically active circulating metabolite produced by humans [3]; it has a half-life of $4-15 \mathrm{~h}[10,11]$ and is responsible for serum calcium and phosphate homeostasis via coordinate effects on the kidney, small intestine, and bone [12]. Indeed, it regulates intestinal calcium and phosphorus absorption [13], 


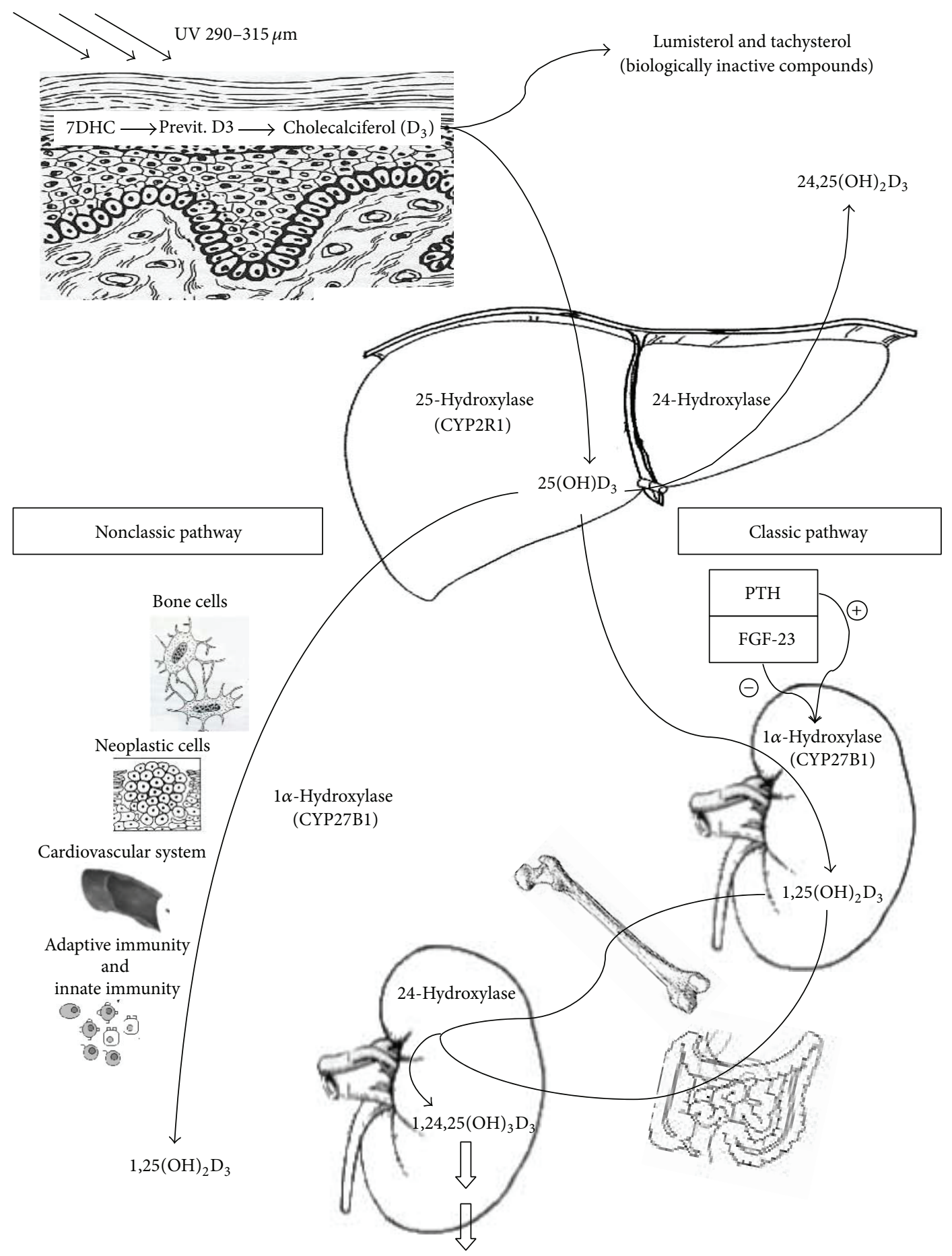

FIgURE 1: Overview of vitamin D metabolism.

calcium mobilization from bone, and renal reabsorption of calcium and phosphorus [14].

The conversion of $25(\mathrm{OH}) \mathrm{D}$ to $1,25(\mathrm{OH})_{2} \mathrm{D}$ depends on the action of the cytochrome P450 enzyme (CYP450), 25 -hydroxyvitamin $\mathrm{D}-1 \alpha$-hydroxylase $(1 \alpha$-OHase), in the kidney. However, a cytochrome P27B1 enzyme (CYP27B1), $1 \alpha$-hydroxylase, activity has also been demonstrated in bone cells, both osteoblasts and osteocytes $[15,16]$; it leads to a local production of $1,25(\mathrm{OH})_{2} \mathrm{D}$ within the osteocytes and directly affects autocrine activities promoting osteoblast and osteocyte maturation and bone remodelling $[16,17]$. In recent years $1 \alpha$-hydroxylase activity has been found in other tissues, such as placenta, skin, immune system, and granuloma tissue [18]. Synthesis of $1,25(\mathrm{OH})_{2} \mathrm{D}$ in the kidney is directly stimulated by $\mathrm{PTH}$ integrating the role of vitamin $\mathrm{D}$ in maintaining mineral homeostasis. In fact hypocalcemia, 
hyperphosphatemia, or reduction in serum fibroblast growth factor 23 (FGF23) results in increased production of PTH that stimulates hydroxylation of 25(OH)D [19]. Conversely, when $1,25(\mathrm{OH})_{2} \mathrm{D}$ levels increase, FGF-23 inhibits CYP27B1 in the proximal renal tubule [20]. Additionally, $1,25(\mathrm{OH})_{2} \mathrm{D}$ is capable of inversely regulating its own levels by inducing the synthesis of 25-hydroxyvitamin D-24-hydroxylase (24OHase) [21]. This enzyme is located essentially ubiquitously in all kinds of cells including renal and intestinal cells. The enzyme is also a mixed-function oxidase cytochrome P450 molecule and catalyzes the hydroxylation on carbon 24 leading to the production of 1,24,25-hydroxyvitamin D, the first step in the 24 oxidation pathway that leads to the formation of an inactive water soluble metabolite, calcitroic acid, which is excreted in the urine [22]. 24-hydroxylase produces metabolite also from $25(\mathrm{OH}) \mathrm{D}$ leading to the production of 24,25-dihydroxyvitamin $\mathrm{D}\left[24,25(\mathrm{OH})_{2} \mathrm{D}\right]$. Showing the intriguing mechanism in vitamin $\mathrm{D}$ metabolism, recently we demonstrated that the administration of high doses of vitamin $\mathrm{D}$ leads to a rapid conversion of $25(\mathrm{OH}) \mathrm{D}$ in both active and inactive $\left[24,25(\mathrm{OH})_{2} \mathrm{D}\right]$ metabolites [23].

The role and the mechanism of action of these metabolites are not well defined [3]; it could be only hypothesized that if a $24,25(\mathrm{OH})_{2} \mathrm{D}$ receptor exists, it would be a member of the nuclear hormone receptor family by analogy with the vitamin $\mathrm{D}$ receptor (VDR) [8]. In fact, as a fat-soluble secosteroid hormone, $1,25(\mathrm{OH})_{2} \mathrm{D}$ carries out its mechanism of action binding an intracellular receptor that is a member of the superfamily of nuclear receptors. VDR forms a heterodimer with the retinoid $\mathrm{X}$ receptor acting as a transcription factor that binds to vitamin $\mathrm{D}$ response elements in the promoter region of target genes. This interaction with specific DNA sequences results in the activation or repression of transcription processes. In addition, other ligand-recruited complexes appear to act more directly on the transcriptional apparatus, known as steroid receptor activator complex (SRC) [24]. VDR is expressed both in classical target organs of vitamin $\mathrm{D}$ involved in mineral homeostasis and in most tissues and cells of the human body explaining the molecular basis of the pleiotropic effect of vitamin D endocrine-system and its nonclassical actions [25]. This system regulates cell proliferation and differentiation and has immunomodulatory, anti-inflammatory, and antifibrotic properties. VDR polymorphisms and different vitamin D metabolisms, involving numerous cytochromes and cytokines, are also considered to be implicated in pathogenetic mechanisms involving numerous systems, for example, cardiovascular [26], metabolic [27], neurological [28], immunological [29], and neoplastic [30] tissues.

\section{Vitamin D and Obesity}

A number of studies have shown that obesity, defined as a body mass index $(\mathrm{BMI}) \geq 30 \mathrm{~kg} / \mathrm{m}^{2}[31,32]$, is associated with low serum 25(OH)D levels [33, 34]. A bidirectional genetic study, which limits confounding, has suggested that higher BMI leads to lower $25(\mathrm{OH}) \mathrm{D}$, each unit increase in BMI being associated with $1.15 \%$ lower concentration of $25(\mathrm{OH}) \mathrm{D}$, after adjusting for age, sex, laboratory batch, and month of measurement [35].

The basis of low vitamin D concentration in obesity is still under debate and could be the result of several mechanisms. One hypothesis is that the high content of body fat acts as a reservoir for lipid soluble vitamin D and increases its sequestration, thus determining its low bioavailability [36]. It has also been reported that fat content is inversely related to serum $25(\mathrm{OH}) \mathrm{D}$ concentration and that this association is stronger than that between $25(\mathrm{OH}) \mathrm{D}$ and BMI [35]. In obese subjects, not only fat mass is increased but also lean body mass, as an adaptative response to greater body weight. In animal studies it has been shown that $25(\mathrm{OH}) \mathrm{D}$ was stored $33 \%$ in fat and $20 \%$ in muscle [37], suggesting that muscle could be also another reservoir of vitamin D in humans. Other authors have theorized that obesity is associated with decreased sunlight exposure, limited outdoor activity, or clothing habits that limits cutaneous vitamin $\mathrm{D}$ synthesis [38]. Another hypothesis is that the synthesis of 25hydroxyvitamin $\mathrm{D}$ by the liver may occur at a lower rate in obese subjects due to hepatic steatosis [39]. An alternative explanation is that higher leptin and interleukin 6 circulating levels, mostly secreted by adipose tissue, may have inhibitory effects on 25(OH)D synthesis via their receptors [40]. Even though these previously reported hypotheses may have a role in explaining the reasons for the high prevalence of hypovitaminosis $\mathrm{D}$ in obesity, a recent study addresses the question by taking into consideration not only BMI but also body size. This study showed that a volumetric dilutional model accounted for essentially all the variability in serum $25(\mathrm{OH}) \mathrm{D}$ concentrations attributable to obesity; in fact once serum $25(\mathrm{OH}) \mathrm{D}$ concentrations in obese individuals are adjusted for body size, there is no longer a difference between obese and nonobese individuals [41].

A difference that certainly characterizes obese subjects is the higher fat mass and researchers are now focusing on the interplay between fat mass and vitamin D. Adipose tissue is nowadays considered as a major active endocrine organ secreting heterogeneous bioactive factors, the socalled adipokines [42]. Humans have two major anatomically distinct types of adipose tissues, white and brown which are derived from different cell lineages and exert opposite roles on lipid metabolism. The white fat stores energy and the brown fat dissipates it by using lipids as fuel for thermogenesis. Fat cells are extremely plastic, able to rapidly expand in size and number. In obesity, adipocytes become enlarged with increased macrophage infiltration and a switch towards the proinflammatory phenotype. Interestingly, the ability to both recruit and differentiate new adipocytes is impaired in individuals with hypertrophic adipose tissue [43]. Differentiation into adipocytes requires key transcription factors like the nuclear receptor peroxisome proliferator-activated receptor $\gamma$ $(\operatorname{PPAR} \gamma)$ and the CCAAT-enhancer-binding proteins [44].

It has been clearly shown that adipose tissue may both regulate and be regulated by vitamin $\mathrm{D}$ [45]. The expression of the vitamin $\mathrm{D}$ receptor, 25 -hydroxyvitamin $\mathrm{D} 1 \alpha$-hydroxylase (CYP27B1) genes, and 24-hydroxylase enzyme has been shown in human adipocytes [46]. There are some experimental data suggesting that vitamin $\mathrm{D}$ could promote greater 
adiposity, leading to elevated parathyroid hormone, which may promote calcium influx into adipocytes thereby enhancing lipogenesis [47]. Also 1,25-hydroxyvitamin D modulates adipogenesis through vitamin $\mathrm{D}$ receptor-dependent inhibition of critical molecular components of adipogenesis such as peroxisome proliferator-activated receptor $\gamma$ [48]. Data on $1,25(\mathrm{OH})_{2} \mathrm{D}$ level are controversial in obese subjects; they are reported to be increased or decreased, probably due to the heterogeneity of the technique used in measuring $1,25(\mathrm{OH})_{2} \mathrm{D}$ by immunoassay, which is not totally specific and measures other vitamin D metabolites in serum $[49,50]$.

The complex biochemical interactions between adipose tissue and vitamin $\mathrm{D}$ in vitro raise the question as to whether hypovitaminosis D, itself, may contribute to obesity or inhibit weight loss in vivo. A few studies have shown that vitamin $\mathrm{D}$, with or without calcium, appears not to have a definite effect on weight, but that it may affect fat mass and distribution. This effect was seen when $25(\mathrm{OH}) \mathrm{D}$ level was less than $50 \mathrm{nmol} / \mathrm{L}$; it was not observed when $25(\mathrm{OH}) \mathrm{D}$ was above this threshold [51-54]. This demonstrated that giving supplemental vitamin $\mathrm{D}$ to those who were replete has no additional effect.

An unresolved question is what dose of vitamin D should be used in obese subjects to replete vitamin $\mathrm{D}$ stores and how to maintain normal $25(\mathrm{OH}) \mathrm{D}$ levels after repletion. The Institute of Medicine (IOM) guidelines suggest that there is no evidence that increases in vitamin $\mathrm{D}$ intake beyond the requirements for nonobese persons can affect bone health or other health conditions among obese persons [55], while Endocrine Society guidelines suggest two to three times more vitamin $\mathrm{D}$ in obese people for their age group to satisfy their body's vitamin D requirement [56].

These conclusions are supported by a recent randomized study of seven doses of vitamin $\mathrm{D}_{3}$ (from $400 \mathrm{IU} / \mathrm{d}$ to $4800 \mathrm{IU} / \mathrm{d}$ ) showing how the response to vitamin D supplementations was dependent on body size. After vitamin D supplementation, all obese women reached adequate levels of serum $25(\mathrm{OH}) \mathrm{D}$, but women with $\mathrm{BMI}<25 \mathrm{~kg} / \mathrm{m}^{2}$ reached much higher levels of $25(\mathrm{OH}) \mathrm{D}$ with the same dose, suggesting that "one size does not fit all": the dose depends on the threshold of vitamin $\mathrm{D}$ to be achieved and on body size [57-61].

However, if the goal is to affect the number of comorbid conditions commonly associated with obesity, where it has been speculated that vitamin $\mathrm{D}$ insufficiency may play a role, such as type 2 diabetes [62], cardiovascular disease [63], and hypertension [64], it is likely that the dose of vitamin $\mathrm{D}$ required to affect these comorbidities may be different from that needed to suppress PTH [57]. It has been suggested that PTH is suppressed at a lower serum $25(\mathrm{OH}) \mathrm{D}$ in obese women compared to the entire population [54]. It is possible that there may be a different set-point for the calcium PTH relationship in the obese, as demonstrated in a calcium-citrate clamp that showed an exaggerated PTH response to hypocalcemia as compared to normal subjects [65]. The etiology for the above is unknown, as well as the dose of vitamin D needed to suppress PTH. Likewise, the dose required to affect comorbidities associated with obesity is uncertain. Considering the effect of vitamin D supplementation on glycaemic indices in obese, $1000 \mathrm{UI} / \mathrm{d}$ had no effect [66], while 4,000 to $10,000 \mathrm{IU} / \mathrm{d}$ had beneficial effect $[67,68]$. Considering the effect on hypertension, a high dose of vitamin $\mathrm{D}_{3}(15,000 \mathrm{IU} / \mathrm{d})$, in obese hypertensive patients, was demonstrated to reduce tissue-renin angiotensin system activity [69]. Regarding cardiovascular disease risk markers in overweight subjects, a vitamin D supplement of $3332 \mathrm{IU} / \mathrm{d}$ was able to significantly reduce triglyceride levels and proinflammatory cytokines [70]. However, Jorde et al. demonstrated that a dose of vitamin D 40000 IU per week had no positive effect on glucose tolerance, blood pressure, or serum lipids in a sample of subjects with sufficient vitamin $\mathrm{D}$ baseline levels [71]. These studies emphasize that only patients with an insufficient vitamin $\mathrm{D}$ level would benefit from vitamin $\mathrm{D}$ supplements, with a dosage that would appear to be higher than the dose needed to obtain only vitamin D sufficiency and thus PTH suppression. However the mechanisms to explain these results are still largely unknown.

This consideration should be extended also to obese patients who undergo bariatric surgery, which is used with an increasing frequency for weight reduction. Indeed, bariatric surgical procedures may induce malabsorption; therefore, the combination of both low preoperative vitamin concentration and malabsorption may render these patients more prone to severe vitamin D deficiencies. Supplementation with vitamin $\mathrm{D}$ should be considered before and after surgery [71]. In any case, clinical studies to determine optimal treatment guidelines for the surgical and nonsurgical population with obesity are warranted.

\section{Vitamin D and Skeletal Muscle}

Vitamin D depletion has been frequently associated with worse physical performance, increased risk of falls, and impaired muscle strength, particularly in the elderly [7281]. While muscle weakness and pain represent the typical pattern of osteomalacic-associated muscle disease, even atypical clinical presentations are frequent. They include hypotonia, waddling gait, impaired physical function, and uniform generalized muscle wasting and bone pain [82].

Vitamin D exerts an important role in the regulation of skeletal muscle tropism and contraction. As for bone, it has been proposed that vitamin $\mathrm{D}$ acts on muscle tissue through both a direct and an indirect effect. The proposed mechanisms include proximal muscle atrophy, loss of type II muscle fibers, and secondary hyperparathyroidism [8387]. Indeed, vitamin $D$ acts to maintain the function of type II muscle fibers $[83,84]$. The histopathological findings showed atrophy of type II skeletal muscle fibers in adults with vitamin D deficiency [85]. This finding is of utmost importance because type II muscle fibers are the first to be recruited when preventing a fall [86].

As far as secondary hyperparathyroidism is concerned, it has been shown that parathyroid hormone negatively affects skeletal muscle function in animal models through proteolysis of muscle proteins and by reducing inorganic phosphate, creatine phosphate, and Ca-ATPase in muscle cells [82]. 
The direct effects of vitamin $\mathrm{D}$ on muscle have to be connected with VDR. Since it was identified in skeletal muscle cells, several reports stated that vitamin $\mathrm{D}$ affects muscle function through the binding of $1,25(\mathrm{OH})_{2} \mathrm{D}$ to its receptor, resulting in muscle growth, as well as other adaptations [74]. Hence, the role of vitamin D on muscle seems to be connected to the induction of genomic effects, leading to the synthesis of new proteins affecting muscle cell contractility, proliferation, and differentiation and to the regulation of calcium transport in the sarcoplasmic reticulum $[87,88]$. Nevertheless, the underlying mechanism is actually not well understood. Data from literature demonstrated that, during development, $1,25(\mathrm{OH})_{2} \mathrm{D}$ decreases cell proliferation and enhances myogenic cell differentiation in the mesodermal stem cells by modulating the expression of key pro- and antimyogenic factors, such as IGF-I, IGF-II, follistatin, and myostatin [88]. Hence, $1,25(\mathrm{OH})_{2} \mathrm{D}$ can affect myogenic differentiation of skeletal muscle cell lines through an upregulation of $I G F-I I$ and follistatin and a downregulation of $I G F$ $I$ and myostatin expression [88]. Garcia et al. demonstrated that the addition of 1,25-dihydroxyvitamin $\mathrm{D}_{3}$ to skeletal muscle cells enhanced the expression of myogenic markers and transcription factors at different stages of differentiation [88]. Moreover, after 10 days of incubation of the cells with 1,25-dihydroxyvitamin $\mathrm{D}_{3}$, muscle fibers turned to be positive for MHC type II, a late myogenic marker, and showed an increase in the mean diameter and in the width, compared to the controls [88].

Recently, the presence of a functional vitamin D system in muscle, including a CYP27B1 bioactivity, has been demonstrated $[86,87]$. This system has been described to act by inhibiting muscle cells proliferation and myotube formation and increasing myotubes size, thus suggesting a direct effect of the hormone on muscle [87]. Conversely, data from Wang and DeLuca demonstrated the absence of vitamin $\mathrm{D}$ receptor on skeletal muscle suggesting that the effect of vitamin $\mathrm{D}$ in muscle function is most likely indirect [89]. These authors also speculated that the muscle impairment of osteomalacia might depend on associated metabolic changes such as hypocalcemia, hypophosphatemia, and elevated PTH levels [89].

A number of clinical studies have reported that a low vitamin D status is associated with loss of handgrip strength and impaired lower extremity function with increased risk of falls [73-80] (Table 1). Moreover, the effect of vitamin D administration on physical performance, falls, and muscle strength has been widely investigated. Short- and long-term studies collectively demonstrate a relationship between vitamin D status and fall prevention and improvement in muscle strength in community-dwelling older individuals receiving a long-term supplementation with calcium and vitamin D [90-92] (Table 1). Nevertheless, data are still conflicting [74, 81, 93-95]. A meta-analysis of eight randomized controlled trials showed that doses of 700 IU to 1000 IU supplemental vitamin $\mathrm{D}_{3}$ a day could reduce falls by $19 \%$ or by up to $26 \%$ in the elderly [96]. This benefit was significant within 25 months and beyond 12 months of treatment; in addition it may not depend on additional calcium supplementation [96]. Active forms of vitamin D were not found to be more effective and vitamin $\mathrm{D}_{3}$ has been reported as possibly better than vitamin $D_{2}$ in preventing falls [96]. Finally, based on the possible better efficacy of higher doses of vitamin $D$, the authors pointed out the need for future research exploring such doses [96]. On the contrary, a double-blind, placebocontrolled trial of 2256 community-dwelling women, aged 70 years or older, considered to be at high risk of fracture, concluded that an annual oral administration of high dose cholecalciferol $(500,000 \mathrm{IU})$ resulted in an increased risk of falls and fractures [97]. Nevertheless, these results were observed early after dosing, being the RR of falls in the vitamin D group 1.31 in the first 3 months (95\% CI, 1.121.54), but only 1.13 (95\% CI, 0.99-1.29) during the remaining months of the year [94].

Other authors found no significant effect of vitamin D supplementation on muscle strength $[94,95]$. A more recent study, by Knutsen et al., reported the absence of any improvement in muscle strength or power (as assessed by jump, handgrip, or chair-rising test) after sixteen weeks of daily supplementation with 1,000 IU of vitamin $\mathrm{D}_{3}$ in a healthy adult population aged 18-50 years with hypovitaminosis D [98]. Such discrepancies could be due to the lack of homogeneity among the populations studied and the different doses of vitamin D used [93-95]. Indeed, some works actually focused on deficient and others on nondeficient patients and the dose scheme was not adequate in some instances to significantly increase vitamin $\mathrm{D}$ serum levels above the threshold of sufficiency [93-95]. On the other hand, the last point is in turn relatedto the fact that the optimal dose and frequency of vitamin D supplementation to achieve and maintain adequate vitamin D serum levels are still debated.

General muscle strength is often evaluated by handgrip strength and/or thigh muscle strength measured by a dynamometer. Gupta et al. reported enhanced handgrip strength in vitamin D deficient Indians aged 20-40 years treated with $60,000 \mathrm{IU}$ per week for 8 weeks followed by $60,000 \mathrm{IU} / \mathrm{month}$ for 4 months of cholecalciferol, combined with calcium [90]. In contrast, Goswami et al. reported no improvement in skeletal muscle strength with such a scheduled supplementation [99]. A recent study from our group represents one of the few ones dealing with the issue of muscle strength and vitamin D supplementation in young chronically D-deficient/insufficient people. We evaluated the effect of a single oral dose of $600,000 \mathrm{IU}$ of cholecalciferol on the handgrip strength in young women with vitamin $\mathrm{D}$ deficiency [100]. The results showed rapidly improved vitamin $\mathrm{D}$ status, while we did not observe any changes in muscle strength parameters in the whole cohort over 3 months, or in a subgroup of women followed up for 6 months. Moreover, 25(OH)D and PTH did not correlate with the two parameters of muscle strength studied at any time point. Finally, we found an increase of serum phosphate in response to vitamin $\mathrm{D}$ administration, which could be the most important mechanism of vitamin $\mathrm{D}$ effect on muscle, as also suggested by the significant correlation between serum phosphorus levels and muscle strength we found after supplementation both in the whole sample and in the subgroup of women followed up for 6 months [100]. However, the small sample size did not allow concluding the possible 
TABLE 1: Effect of vitamin D on muscle strength and falls.

\begin{tabular}{|c|c|c|}
\hline $\begin{array}{l}\text { Author, year, and } \\
\text { study type }\end{array}$ & Patients, age & Endpoints/tools \\
\hline $\begin{array}{l}\text { Visser et al., } 2003[73] \text {; } \\
\text { prospective } \\
\text { observational } \\
\text { study }\end{array}$ & $\begin{array}{l}1008 \text { for grip strength } \\
\text { evaluation; } 331 \text { for } \\
\text { muscle mass } \\
\text { evaluation; } 55-85 \text { yrs }\end{array}$ & $\begin{array}{l}\text { Grip strength; } \\
\text { appendicular skeletal } \\
\text { muscle mass (using } \\
\text { dual-energy X-ray } \\
\text { absorptiometry) }\end{array}$ \\
\hline $\begin{array}{l}\text { Latham et al., } 2003 \\
{[101] ; \text { multicenter, }} \\
\text { RCT }^{*}\end{array}$ & $\begin{array}{l}243 \\
\text { hospitalized } \\
\text { patients; } \\
65 \text { yrs or older }\end{array}$ & $\begin{array}{l}\text { Falls, physical performance } \\
\text { (isometric knee extensor } \\
\text { strength), and self-rated } \\
\text { function }\end{array}$ \\
\hline $\begin{array}{l}\text { Kenny et al., } 2003 \\
\text { [95]; RCT* }\end{array}$ & $\begin{array}{l}65 \text { healthy, } \\
\text { community-dwelling } \\
\text { men; } 65-87 \text { yrs }\end{array}$ & $\begin{array}{l}\text { Upper and lower extremity } \\
\text { muscle strength and power } \\
\text { (using a leg press and } \\
\text { handgrip strength), } \\
\text { physical performance } \\
\text { (specific tests), and activity } \\
\text { (using questionnaires) }\end{array}$ \\
\hline
\end{tabular}

\begin{tabular}{lll}
\hline $\begin{array}{l}\text { Broe et al., 2007 [75]; } \\
\text { secondary data } \\
\text { analysis of a previous } \\
\text { RCT* }\end{array}$ & $\begin{array}{l}\text { 124 nursing-home } \\
\text { residents; 68-104 yrs }\end{array}$ & Falls \\
\hline $\begin{array}{l}\text { Bischoff-Ferrari et al., } \\
\begin{array}{l}2004 \text { [78]; } \\
\text { population-based } \\
\text { survey }\end{array}\end{array}$ & $\begin{array}{l}\text { Ambulatory } \\
\text { population; 60-90 yrs }\end{array}$ & $\begin{array}{l}\text { Lower-extremity function; } \\
\text { timed 8-foot walk test; and } \\
\text { repeated sit-to-stand test }\end{array}$ \\
\hline
\end{tabular}

Result

(i) Persons with baseline 25-OHD levels

$<25 \mathrm{nmol} /$ liter were 2.57 (based on grip strength) and 2.14 (based on muscle mass) times more likely to experience sarcopenia, compared with those with levels $>50 \mathrm{nmol} /$ liter

(ii) $\mathrm{PTH}>4.0 \mathrm{pmol} /$ liter was associated with an increased risk of sarcopenia

No effect of vitamin D (calciferol, 300,000 IU) on physical health, falls, and physical performance, even in patients with baseline vitamin D levels $<12 \mathrm{ng} / \mathrm{mL}$

(i) Baseline 25OHD correlated with baseline single-leg stance time and physical activity score. Baseline PTH levels correlated with baseline 8-foot walk time and physical activity score

(ii) No significant difference in strength, power, and physical performance between groups (cholecalciferol 1,000 IU/d or placebo for 6 months, all received $500 \mathrm{mg}$ of calcium)

Supplementation with 800 IU of cholecalciferol reduced the adjusted-incidence rate ratio of falls by $72 \%$, compared to placebo; no differences for the 200, 400, and $600 \mathrm{IU}$ dose

The group in the highest quintiles of $25(\mathrm{OH}) \mathrm{D}$ had an average decrease of $0.27 \mathrm{~s}$ in the 8 -foot walk test and an average decrease of $0.67 \mathrm{~s}$ in the sit-to-stand test

Gerdhem et

al., 2005 [77];

prospective

$986 ; 75.0-75.9$ yrs

Gait, balance, and observational study

Houston et al., 2007 [81]; post hoc analysis of a prospective population-based study

\section{6; 65 yrs or older}

Short physical performance battery (SPPB) and handgrip strength
25OHD correlated with gait speed $(P<0.001)$, balance test $(P<0.001)$, self-estimated activity level $(P<0.001)$, and thigh muscle strength $(P=0.02)$ thigh muscle strength

(i) Vitamin D levels were significantly associated with SPPB score in men $(P=0.04)$ and handgrip strength in men $(P=0.004)$ and women $(P=0.01)$

(ii) Men and women with serum 25OHD $<25.0 \mathrm{nmol} / \mathrm{L}$ had significantly lower SPPB score; and those with serum $25 \mathrm{OHD}<50 \mathrm{nmol} / \mathrm{L}$ had significantly lower handgrip strength than those with serum $25 \mathrm{OHD} \geq 25$ and $\geq 50 \mathrm{nmol} / \mathrm{L}$, respectively, $(P<0.05)$

(iii) PTH was significantly associated with handgrip strength only $(P=0.01)$

(i) Calcium plus vitamin D significantly decreased the number of subjects with first falls of $27 \%$ at month 12 and $39 \%$ at month 20, compared to calcium alone

Pfeifer et al., 2009

[91];

double-blind, controlled trial

\section{2}

community-dwelling people; 70 yrs or older
Falls, body sway, timed-up-and-go test, and maximum isometric leg extensor strength (assessed with a strain gauge dynamometer)

(ii) Significant improvements in quadriceps strength of $8 \%$, a decrease in body sway of $28 \%$, and a decrease in time needed to perform the TUG test of $11 \%$

Maximum isometric strength of hip flexors (SHF) and knee extensors (SKE), measured by a portable mechanical dynamometer
SHF was increased in the calcium/vitamin D group (1 g calcium + cholecalciferol 150,000 IU once a month for the first 2 months and then 90,000 IU once a month for the last 4 months) by $16.4 \%$ $(P=0.0001)$ and SKE by $24.6 \%(P=0.0007)$, no improvement in the calcium + placebo group 
TABle 1: Continued.

\begin{tabular}{|c|c|c|c|}
\hline $\begin{array}{l}\text { Author, year, and } \\
\text { study type }\end{array}$ & Patients, age & Endpoints/tools & Result \\
\hline $\begin{array}{l}\text { Kukuljan et al., } 2009 \\
\text { [93]; RCT* }\end{array}$ & $\begin{array}{l}180 \text { healthy men, } \\
50-79 \text { yrs }\end{array}$ & $\begin{array}{l}\text { Total body lean and fat } \\
\text { mass }\left(\mathrm{DXA}^{\wedge}\right) \text {, midfemur } \\
\text { muscle cross-sectional area } \\
\text { (quantitative computed } \\
\text { tomography), muscle } \\
\text { strength, and physical } \\
\text { function }\end{array}$ & $\begin{array}{l}\text { Daily consumption of low-fat fortified milk } \\
\text { (providing } 1000 \mathrm{mg} \text { calcium and } 800 \mathrm{IU} \text { vitamin } \mathrm{D}_{3} \text {, } \\
\text { per day) does not enhance the effects of resistance } \\
\text { training exercise on skeletal muscle size, strength, or } \\
\text { function }\end{array}$ \\
\hline $\begin{array}{l}\text { Bischoff-Ferrari et al., } \\
2009 \text { [96]; } \\
\text { meta-analysis of } \\
\text { RCT }^{*}\end{array}$ & $\begin{array}{l}2426 \text { patients from } 8 \\
\text { RCT }\end{array}$ & Falls & $\begin{array}{l}\text { (i) High dose supplemental vitamin D reduced fall } \\
\text { risk by } 19 \% \\
\text { (ii) Achieved serum } 25(\mathrm{OH}) \mathrm{D} \text { concentrations of } \\
60 \mathrm{nmol} / \mathrm{L} \text { or more resulted in a } 23 \% \text { fall reduction }\end{array}$ \\
\hline $\begin{array}{l}\text { Lips et al., } 2010[94] \text {; } \\
\text { double-blind, } \\
\text { placebo-controlled } \\
\text { trial }\end{array}$ & $\begin{array}{l}126 \text { patients with } \\
\text { vitamin } D \\
\text { insufficiency; } 70 \text { yrs or } \\
\text { older }\end{array}$ & $\begin{array}{l}\text { Mediolateral body sway and } \\
\text { short physical performance } \\
\text { battery (SPPB) }\end{array}$ & $\begin{array}{l}\text { (i) After } 16 \text { wk, mediolateral sway and SPPB did not } \\
\text { differ significantly between treatment groups } \\
\text { (vitamin } D_{3} 8400 \mathrm{IU} / \text { week versus placebo) } \\
\text { (ii) In the post hoc analysis treatment with vitamin } \\
\mathrm{D}_{3} \text { significantly reduced sway compared with } \\
\text { placebo }(P=0.047) \text { in patients with elevated } \\
\text { baseline sway }\end{array}$ \\
\hline
\end{tabular}

\begin{tabular}{|c|c|c|c|}
\hline $\begin{array}{l}\text { Gupta et al., } 2010[90] \\
\text { double-blind, } \\
\text { randomized trial }\end{array}$ & $\begin{array}{l}40 \text { healthy volunteers; } \\
20-40 \text { yrs }\end{array}$ & $\begin{array}{l}\text { Handgrip and gastrosoleus } \\
\text { dynamometry, pinch-grip } \\
\text { strength, respiratory } \\
\text { pressures, 6-minute walk } \\
\text { test, and muscle energy } \\
\text { Metabolism on }{ }^{P 1^{P}} \\
\text { magnetic resonance } \\
\text { spectroscopy }\end{array}$ & $\begin{array}{l}\text { The supplemented group }\left(60,000 \mathrm{IU} \mathrm{D}_{3} / \text { week for } 8\right. \\
\text { weeks followed by } 60,000 \mathrm{IU} / \mathrm{month} \text { for } 4 \text { months }+ \\
1 \mathrm{~g} \text { of calcium daily) gained a handgrip strength of } \\
2 Æ 4 \mathrm{~kg} \text {; gastrosoleus strength of } 3 Æ 0 \mathrm{Nm} \text {; and } \\
\text { walking distance of } 15 Æ 9 \mathrm{~m} \text { over the placebo group }\end{array}$ \\
\hline $\begin{array}{l}\text { Murad et al., } 2011 \\
{[76] ;} \\
\text { meta-analysis }\end{array}$ & $\begin{array}{l}45,782 \text { participants } \\
\text { from } 26 \text { trials }\end{array}$ & Falls & $\begin{array}{l}\text { Vitamin D use was associated with statistically } \\
\text { significant reduction in the risk of falls (odds ratio } \\
\text { for suffering at least one fall, } 0.86 ; 95 \% \text { confidence } \\
\text { interval, } 0.77-0.96 \text { ) }\end{array}$ \\
\hline $\begin{array}{l}\text { Goswami et al., } 2012 \\
\text { [99]; RCT }\end{array}$ & $\begin{array}{l}173 \text { healthy females, } \\
\text { mean age } 21.7+4.4 \text { yrs }\end{array}$ & $\begin{array}{l}\text { Handgrip and pinch grip } \\
\text { strength and distance } \\
\text { walked in } 6 \mathrm{~min}\end{array}$ & $\begin{array}{l}\text { Mean handgrip strength and its increase were } \\
\text { comparable in } 4 \text { groups (double placebo, } \\
\text { calcium/placebo, cholecalciferol/placebo, and } \\
\text { cholecalciferol/calcium at } 6 \text { months) }\end{array}$ \\
\hline $\begin{array}{l}\text { Cipriani et al., } 2013 \\
\text { [100]; prospective } \\
\text { intervention } \\
\text { study }\end{array}$ & $\begin{array}{l}18 \text { women with vitamin } \\
\text { D deficiency } \\
(25-39 \text { yrs })\end{array}$ & $\begin{array}{l}\text { Handgrip strength (using a } \\
\text { dynamometer and } \\
\text { evaluating maximal } \\
\text { voluntary contraction } \\
\text { (MVC) and speed of } \\
\text { contraction }(S) \text { ) }\end{array}$ & $\begin{array}{l}\text { (i) No significant change in MVC and } S \text { values after } \\
\text { vitamin D supplementation (cholecalciferol } \\
600,000 \mathrm{IU}) \\
\text { (ii) A significant correlation between MVC and } S \\
\text { and serum phosphorus after supplementation } \\
(P<0.02 \text { and } P<0.05 \text {, resp.) }\end{array}$ \\
\hline $\begin{array}{l}\text { Knutsen et al., } 2014 \\
\text { [98]; RCT }\end{array}$ & $\begin{array}{l}251 \text { healthy adults with } \\
\text { vitamin D deficiency } \\
(18-50 \mathrm{yrs})\end{array}$ & $\begin{array}{l}\text { Jump height, handgrip } \\
\text { strength, and chair-rising } \\
\text { test }\end{array}$ & $\begin{array}{l}\text { (i) Percentage change in jump height did not differ } \\
\text { between the group receiving vitamin } \mathrm{D}_{3}(1000 \mathrm{IU} \\
\text { daily) and placebo }(P=0.44) \\
\text { (ii) No significant effect of vitamin D on handgrip } \\
\text { strength or the chair-rising test }\end{array}$ \\
\hline
\end{tabular}

\footnotetext{
${ }^{*}$ Randomized controlled trial.

${ }^{\wedge}$ Dual-energy X-ray absorptiometry.
}

mechanisms underlying our results, particularly those related to the effect of high $1,25(\mathrm{OH})_{2}$ levels on muscle tissue [100].

As discussed in experimental data, clinical studies reported conflicting results, demonstrating that the effect of vitamin $\mathrm{D}$ on muscle strength and performance still presents many controversial issues and open questions [101, 102] that need to be addressed also in relation to the reported variation in vitamin D receptor gene [103]. The discordant results are substantially connected to the high variability in terms of study design and muscle parameters considered as outcomes and also reflect the discordant findings on the mechanisms underlying vitamin D and muscle function. Among all, the possible direct effect of the hormone on muscle tissue is still controversial, since opposite data are available on VDR expre ssion on skeletal muscle $[83,89]$. Moreover, the metabolic changes associated with vitamin $\mathrm{D}$ deficiency have 
been suggested to be related to a muscle strength improvement after vitamin D supplementation [100]. Hence, given the important action of vitamin D on skeletal muscle tissue, a better understanding of the mechanisms involved is needed, as it will give a new insight into the clinical management of deficient patients.

\section{Conclusion}

Vitamin D represents one of the most studied and discussed topics in the field of bone and mineral metabolism diseases worldwide. The metabolism of the hormone has been extensively clarified, particularly the role of the different enzymes involved, as well as the active and inactive metabolites and the vitamin D receptor. Taken together, these data have also allowed best investigating the pleiotropic and multiorgantargeted effects of vitamin D. In particular, several studies described the interrelationship between the hormone and the adipose tissue, both considering obesity as a predisposing condition to hypovitaminosis $\mathrm{D}$ and vitamin $\mathrm{D}$ as a cofactor in the pathogenesis of obesity. Moreover, direct and indirect effects of the hormone on the skeletal muscle tissue lead to a better understanding of the clinical features associated with vitamin $\mathrm{D}$ deficiency.

As many efforts have been made in the understanding of vitamin D metabolism and functions, several mechanisms still need to be covered, particularly in relation to many genetic factors involved. Additionally, notwithstanding the whole amount of data on the field, no consensus currently exists on definition and treatment regimen of hypovitaminosis D, mostly as far as particular conditions (such as obesity) and targeting functions (as muscle strength) are concerned.

\section{Conflict of Interests}

The authors declare that there is no conflict of interests regarding the publication of this paper.

\section{References}

[1] M. F. Holick, J. A. MacLaughlin, and S. H. Doppelt, "Regulation of cutaneous previtamin $\mathrm{D}_{3}$ photosynthesis in man: skin pigment is not an essential regulator," Science, vol. 211, no. 4482, pp. 590-593, 1981.

[2] H. E. C. Hanwell, R. Vieth, D. E. C. Cole et al., "Sun exposure questionnaire predicts circulating 25-hydroxyvitamin D concentrations in Caucasian hospital workers in southern Italy," Journal of Steroid Biochemistry and Molecular Biology, vol. 121, no. 1-2, pp. 334-337, 2010.

[3] W. D. Fraser and A. M. Milan, "Vitamin D assays: past and present debates, difficulties, and developments," Calcified Tissue International, vol. 92, no. 2, pp. 118-117, 2013.

[4] M. F. Holick, "Sunlight, UV-radiation, vitamin D and skin cancer: how much sunlight do we need?" Advances in Experimental Medicine and Biology, vol. 624, pp. 1-15, 2008.

[5] M. F. Holick, "The cutaneous photosynthesis of previtamin $\mathrm{D}_{3}$ : a unique photoendocrine system," Journal of Investigative Dermatology, vol. 77, no. 1, pp. 51-58, 1981.
[6] A. Slominski, J. Zjawiony, J. Wortsman et al., "A novel pathway for sequential transformation of 7-dehydrocholesterol and expression of the P450scc system in mammalian skin," European Journal of Biochemistry, vol. 271, no. 21, pp. 4178-4188, 2004.

[7] A. T. Slominski, T. K. Kim, W. Li, A. K. Yi, A. Postlethwaite, and R. C. Tuckey, "The role of CYP11Al in the production of vitamin $\mathrm{D}$ metabolites and their role in the regulation of epidermal functions," Journal of Steroid Biochemistry and Molecular Biology, 2013.

[8] R. St-Arnaud and F. H. Glorieux, "24,25 dihydroxyvitamin Dactive metabolite or inactive catabolite?" Endocrinology, vol. 139, no. 8, pp. 341-349, 1998.

[9] T. L. Clemens, X.-Y. Zhou, and M. Myles, "Serum vitamin $\mathrm{D}_{2}$ and vitamin $\mathrm{D}_{3}$ metabolite concentrations and absorption of vitamin $\mathrm{D}_{2}$ in elderly subjects," Journal of Clinical Endocrinology and Metabolism, vol. 63, no. 3, pp. 656-660, 1986.

[10] R. W. Gray, A. E. Caldas, and D. R. Wilz, "Metabolism and excretion of $3 \mathrm{H}-1,25-(\mathrm{OH}) 2$-vitamin $\mathrm{D}_{3}$ in healthy adults," Journal of Clinical Endocrinology and Metabolism, vol. 46, no. 5, pp. 756-765, 1978.

[11] G. Jones, "Pharmacokinetics of vitamin D toxicity," American Journal of Clinical Nutrition, vol. 88, supplement 2, pp. 582S586S, 2008.

[12] A. G. Turner, P. H. Anderson, and H. A. Morris, "Vitamin D and bone health," Scandinavian Journal of Clinical and Laboratory Investigation, vol. 72, no. 243, pp. 65-72, 2012.

[13] J. F. Aloia, R. Dhaliwal, A. Shieh et al., "Vitamin D supplementation increases calcium absorption without a threshold effect," American Journal of Clinical Nutrition, 2013.

[14] M. R. Haussler, G. K. Whitfield, I. Kaneko et al., "Molecular mechanisms of vitamin D action," Calcified Tissue International, vol. 92, no. 2, pp. 77-98, 2013.

[15] R. T. Turner, J. E. Puzas, and M. D. Forte, "In vitro synthesis of $1 \alpha, 25$-dihydroxycholecalciferol and 24,25dihydroxycholecalciferol by isolated calvarial cells," Proceedings of the National Academy of Sciences of the United States of America, vol. 77, no. 10, pp. 5720-5724, 1980.

[16] P. H. Anderson and G. J. Atkins, "The skeleton as an intracrine organ for vitamin D metabolism," Molecular Aspects of Medicine, vol. 29, no. 6, pp. 397-406, 2008.

[17] A. G. Turner, M. A. Hanrath, H. A. Morris, G. J. Atkins, and P. H. Anderson, "The local production of $1,25(\mathrm{OH})_{2} \mathrm{D}_{3}$ promotes osteoblast and osteocyte maturation," Journal of Steroid Biochemistry and Molecular Biology, 2013.

[18] D. Zehnder, R. Bland, M. C. Williams et al., "Extrarenal expression of 25-hydroxyvitamin $\mathrm{D}_{3-1} \alpha$-hydroxylase," Journal of Clinical Endocrinology and Metabolism, vol. 86, no. 2, pp. 888894, 2001.

[19] K. Takeyama, S. Kitanaka, T. Sato, M. Kobori, J. Yanagisawa, and S. Kato, "25-Hydroxyvitamin $\mathrm{D}_{3} 1 \alpha$-hydroxylase and vitamin D synthesis," Science, vol. 277, no. 5333, pp. 1827-1830, 1997.

[20] R. P. Heany, "Vitamin D: role in the calcium economy," in Vitamin D, D. Feldman, F. H. Glorieux, and J. W. Pike, Eds., pp. 485-497, Academic Press, San Diego, Calif, USA, 1997.

[21] G. Makin, D. Lohnes, V. Byford, R. Ray, and G. Jones, “Target cell metabolism of 1,25-dihydroxyvitamin $\mathrm{D}_{3}$ to calcitroic acid. Evidence for a pathway in kidney and bone involving 24oxidation," Biochemical Journal, vol. 262, no. 1, pp. 173-180, 1989.

[22] T. Sakaki, K. Yasuda, A. Kittaka, K. Yamamoto, and T. C. Chen, "CYP24A1 as a potential target for cancer therapy," Anticancer Agents in Medicinal Chemistry, vol. 14, no. 1, pp. 97-108, 2014. 
[23] C. Cipriani, E. Romagnoli, J. Pepe et al., "Long-term bioavailability after a single oral or intramuscular administration of 600,000 IU of ergocalciferol or cholecalciferol: implications for treatment and prophylaxis," Journal of Clinical Endocrinology and Metabolism, vol. 98, no. 7, pp. 2709-2715, 2013.

[24] A. L. Sutton and P. N. MacDonald, "Vitamin D: more than a "bone-a-fide" hormone," Molecular Endocrinology, vol. 17, no. 5, pp. 777-791, 2003.

[25] D. Bikle, "Nonclassic actions of vitamin D," Journal of Clinical Endocrinology and Metabolism, vol. 94, no. 1, pp. 26-34, 2009.

[26] A. G. Pittas, M. Chung, T. Trikalinos et al., "Systematic review: vitamin D and cardiometabolic outcomes," Annals of Internal Medicine, vol. 152, no. 5, pp. 307-314, 2010.

[27] A. Didriksen, G. Grimnes, M. S. Hutchinson et al., "The serum 25-hydroxyvitamin D response to vitamin D supplementation is related to genetic factors, BMI, and baseline levels," European Journal of Endocrinology, vol. 169, no. 5, pp. 559-597, 2013.

[28] J. W. Miller, "Editorial: vitamin D and cognitive function in older adults: are we concerned about vitamin D-mentia?" Neurology, vol. 74, no. 1, pp. 13-15, 2010.

[29] L. L. Ritterhouse, S. R. Crowe, T. B. Niewold et al., "Vitamin D deficiency is associated with an increased autoimmune response in healthy individuals and in patients with systemic lupus erythematosus," Annals of the Rheumatic Diseases, vol. 70, no. 9, pp. 1569-1574, 2011

[30] D. M. Freedman, A. C. Looker, S. Chang, and B. I. Graubard, "Prospective study of serum vitamin D and cancer mortality in the United States," Journal of the National Cancer Institute, vol. 99, no. 21, pp. 1594-1602, 2007.

[31] A. Coin, G. Sergi, N. Minicuci et al., "Fat-free mass and fat mass reference values by dual-energy X-ray absorptiometry (DEXA) in a 20-80 year-old Italian population," Clinical Nutrition, vol. 27, no. 1, pp. 87-94, 2008.

[32] A. Coin, S. Giannini, N. Minicuci et al., "Limb fat-free mass and fat mass reference values by dual-energy $\mathrm{X}$-ray absorptiometry (DEXA) in a 20-80 year-old italian population," Clinical Nutrition, vol. 31, no. 4, pp. 506-511, 2012.

[33] Vanlint, "Vitamin D and obesity," Nutrients, vol. 5, no. 3, pp. 949-956, 2013.

[34] I. González-Molero, G. Rojo-Martínez, S. Morcillo et al., "Hypovitaminosis D and incidence of obesity: a prospective study," European Journal of Clinical Nutrition, vol. 67, no. 6, pp. 680-682, 2013.

[35] K. S. Vimaleswaran, D. J. Berry, C. Lu et al., "Causal relationship between obesity and vitamin D status: bi-directional Mendelian randomization analysis of multiple cohorts," PloS Medicine, vol. 10, no. 2, Article ID e1001383, 2013.

[36] J. Wortsman, L. Y. Matsuoka, T. C. Chen, Z. Lu, and M. F. Holick, "Decreased bioavailabilityof vitamin D in obesity," American Journal Clinical Nutrition, vol. 72, no. 3, pp. 690-693, 2000.

[37] E. B. Mawer, J. Backhouse, C. A. Holman, G. A. Lumb, and S. W. Stanbury, "The distribution and storage of vitamin D and its metabolites in human tissues," Clinical Science, vol. 43, no. 3, pp. 413-431, 1972.

[38] H. Florez, R. Martinez, W. Chacra, N. Strickman-Stein, and S. Levis, "Outdoor exercise reduces the risk of hypovitaminosis $\mathrm{D}$ in the obese," Journal of Steroid Biochemistry and Molecular Biology, vol. 103, no. 3-5, pp. 679-681, 2007.

[39] G. Targher, L. Bertolini, L. Scala et al., "Associations between serum 25-hydroxyvitamin $\mathrm{D}_{3}$ concentrations and liver histology in patients with non-alcoholic fatty liver disease," Nutrition,
Metabolism and Cardiovascular Diseases, vol. 17, no. 7, pp. 517524, 2007.

[40] C. Ding, V. Parameswaran, L. Blizzard, J. Burgess, and G. Jones, "Not a simple fat-soluble vitamin: changes in serum $25-(\mathrm{OH}) \mathrm{D}$ levels are predicted by adiposity and adipocytokines in older adults," Journal of Internal Medicine, vol. 268, no. 5, pp. 501-510, 2010.

[41] A. T. Drincic, L. A. G. Armas, E. E. Van Diest, and R. P. Heaney, "Volumetric dilution, rather than sequestration best explains the low vitamin D status of obesity," Obesity, vol. 20, no. 7, pp. 1444-1448, 2012.

[42] T. Romacho, M. Elsen, D. Röhrborn, and J. Eckel, "Adipose tissue and its role in organ crosstalk," Acta Physiologica, vol. 210, no. 4, pp. 733-753, 2014.

[43] B. Gustafson, A. Hammarstedt, S. Hedjazifar, and U. Smith, "Restricted adipogenesis in hypertrophic obesity: the role of WISP2, WNT, and BMP4," Diabetes, vol. 62, no. 9, pp. 29973004, 2013.

[44] E. Mueller, "Understanding the variegation of fat: novel regulators of adipocyte differentiation and fat tissue biology," Biochimica Et Biophysica Acta, vol. 1842, no. 3, pp. 352-357, 2014.

[45] C. P. Earthman, L. M. Beckman, K. Masodkar, and S. D. Sibley, "The link between obesity and low circulating 25hydroxyvitamin D concentrations: considerations and implications," International Journal of Obesity, vol. 36, no. 3, pp. 387396, 2012.

[46] J. Li, M. E. Byrne, E. Chang et al., " $1 \alpha, 25$-Dihydroxyvitamin D hydroxylase in adipocytes," Journal of Steroid Biochemistry and Molecular Biology, vol. 112, no. 1-3, pp. 122-126, 2008.

[47] M. F. McCarty and C. A. Thomas, "PTH excess may promote weight gain by impeding catecholamine-induced lipolysisimplications for the impact of calcium, vitamin $\mathrm{D}$, and alcohol on body weight," Medical Hypotheses, vol. 61, no. 5-6, pp. 535542, 2003.

[48] K. vinh quốc Lu'o’ng and L. T. Hoàng Nguyễn, “The beneficial role of vitamin D in obesity: possible genetic and cell signaling mechanisms," Nutritional Journal, vol. 12, p. 89, 2013.

[49] S. Konradsen, H. Ag, F. Lindberg, S. Hexeberg, and R. Jorde, "Serum 1,25-dihydroxy vitamin D is inversely associated with body mass index," European Journal of Nutrition, vol. 47, no. 2, pp. 87-91, 2008.

[50] A. Salehpour, F. Hosseinpanah, F. Shidfar et al., "A 12-week double-blind randomized clinical trial of vitamin $\mathrm{D}_{3}$ supplementation on body fat mass in healthy overweight and obese women," Nutritional Journal, vol. 11, p. 78, 2012.

[51] M. Sneve, Y. Figenschau, and R. Jorde, "Supplementation with cholecalciferol does not result in weight reduction in overweight and obese subjects," European Journal of Endocrinology, vol. 159, no. 6, pp. 675-684, 2008.

[52] L. Wamberg, U. Kampmann, H. Stødkilde-Jørgensen, L. Rejnmark, S. B. Pedersen, and B. Richelsen, "Effects of vitamin D supplementation on body fat accumulation, inflammation, and metabolic risk factors in obese adults with low vitamin D levelsresults from a randomized trial," European Journal of Internal Medicine, vol. 24, no. 7, pp. 644-649, 2013.

[53] M. J. Soares, W. Chan She Ping-Delfos, and M. H. Ghanbari, "Calcium and vitamin D for obesity: a review of randomized controlled trials," European Journal of Clinical Nutrition, vol. 65, no. 9, pp. 994-1004, 2011.

[54] S. A. Shapses, E. J. Lee, D. Sukumar, R. Durazo-Arvizu, and S. H. Schneider, "The effect of obesity on the relationship 
between serum parathyroid hormone and 25-hydroxyvitamin D in women," Journal of Clinical Endocrinology and Metabolism, vol. 98, no. 5, pp. E886-E890, 2013.

[55] A. C. Ross, J. E. Manson, S. A. Abrams et al., "The 2011 report on dietary reference intakes for calcium and vitamin $\mathrm{D}$ from the Institute of Medicine: what clinicians need to know," Journal of Clinical Endocrinology and Metabolism, vol. 96, no. 1, pp. 53-58, 2011.

[56] M. F. Holick, N. C. Binkley, H. A. Bischoff-Ferrari et al., "Evaluation, treatment, and prevention of vitamin D deficiency: an endocrine society clinical practice guideline," Journal of Clinical Endocrinology and Metabolism, vol. 96, no. 7, pp. 19111930, 2011.

[57] E. Romagnoli, J. Pepe, S. Piemonte, C. Cipriani, and S. Minisola, "Management of endocrine disease: value and limitations of assessing vitamin D nutritional status and advised levels of vitamin D supplementation," European Journal of Endocrinology, vol. 169, no. 4, pp. R59-R69, 2013.

[58] S. Minisola, L. Colangelo, M. Cilli, C. Cipriani, J. Pepe, and E. Romagnoli, "Intermittent high doses of vitamin d: a need for further studies?" Calcified Tissue International, vol. 92, no. 5, pp. 487-488, 2013.

[59] D. Maggio, A. Cherubini, F. Lauretani et al., "25(OH)D serum levels decline with age earlier in women than in men and less efficiently prevent compensatory hyperparathyroidism in older adults," Journals of Gerontology A Biological Sciences and Medical Sciences, vol. 60, no. 11, pp. 1414-1419, 2005.

[60] J. C. Gallagher, V. Yalamanchili, and L. M. Smith, "The effect of vitamin D supplementation on serum $25(\mathrm{OH}) \mathrm{D}$ in thin and obese women," Journal of Steroid Biochemistry and Molecular Biology, vol. 136, pp. 195-200, 2013.

[61] E. Grethen, R. McClintock, C. E. Gupta et al., "Vitamin D and hyperparathyroidism in obesity," Journal of Clinical Endocrinology and Metabolism, vol. 96, no. 5, pp. 1320-1326, 2011.

[62] Y. C. Ku, M. E. Liu, C. S. Ku, T. Y. Liu, and S. L. Lin, "Relationship between vitamin D deficiency and cardiovascular disease," World Journal of Cardiology, vol. 5, no. 9, pp. 337-346, 2013.

[63] J. Mitri, M. D. Muraru, and A. G. Pittas, "Vitamin D and type 2 diabetes: a systematic review," European Journal of Clinical Nutrition, vol. 65, no. 9, pp. 1005-1015, 2011.

[64] J. P. Forman, E. Giovannucci, M. D. Holmes et al., "Plasma 25hydroxyvitamin D levels and risk of incident hypertension," Hypertension, vol. 49, no. 5, pp. 1063-1069, 2007.

[65] H. Hultin, K. Edfeldt, M. Sundbom, and P. Hellman, "Leftshifted relation between calcium and parathyroid hormone in obesity," Journal of Clinical Endocrinology and Metabolism, vol. 95, no. 8, pp. 3973-3981, 2010.

[66] A. Salehpour, F. Shidfar, F. Hosseinpanah, M. Vafa, M. Razaghi, and F. Amiri, "Does vitamin $\mathrm{D}_{3}$ supplementation improve glucose homeostasis in overweight or obese women? A doubleblind, randomized, placebo-controlled clinical trial," Diabetic Medicine, vol. 30, no. 12, pp. 1477-1481, 2013.

[67] J. Nagpal, J. N. Pande, and A. Bhartia, "A double-blind, randomized, placebo-controlled trial of the short-term effect of vitamin $\mathrm{D}_{3}$ supplementation on insulin sensitivity in apparently healthy, middle-aged, centrally obese men," Diabetic Medicine, vol. 26, no. 1, pp. 19-27, 2009.

[68] A. M. Belenchia, A. K. Tosh, L. S. Hillman, and C. A. Peterson, "Correcting vitamin D insufficiency improves insulin sensitivity in obese adolescents: a randomized controlled trial," American Journal of Clinical Nutrition, vol. 97, no. 4, pp. 774-781, 2013.
[69] A. Vaidya, J. P. Forman, and J. S. Williams, "Vitamin D and the vascular sensitivity to angiotensin II in obese Caucasians with hypertension," Journal of Human Hypertension, vol. 25, no. 11, pp. 672-678, 2011.

[70] A. Zittermann, S. Frisch, H. K. Berthold et al., "Vitamin D supplementation enhances the beneficial effects of weight loss on cardiovascular disease risk markers," American Journal of Clinical Nutrition, vol. 89, no. 5, pp. 1321-1327, 2009.

[71] R. Jorde, M. Sneve, P. Torjesen, and Y. Figenschau, "No improvement in cardiovascular risk factors in overweight and obese subjects after supplementation with vitamin $\mathrm{D}_{3}$ for 1 year: original Article," Journal of Internal Medicine, vol. 267, no. 5, pp. 462-472, 2010.

[72] A. J. Torres and M. A. Rubio, "The Endocrine Society's clinical practice guideline on endocrine and nutritional management of the post-bariatric surgery patient: commentary from a European perspective," European Journal of Endocrinology, vol. 165, no. 2, pp. 171-176, 2011.

[73] M. Visser, D. J. H. Deeg, and P. Lips, "Low vitamin D and high parathyroid hormone levels as determinants of loss of muscle strength and muscle mass (Sarcopenia): the longitudinal aging study Amsterdam," Journal of Clinical Endocrinology and Metabolism, vol. 88, no. 12, pp. 5766-5772, 2003.

[74] A. J. Dirks-Naylor and S. Lennon-Edwards, "The effects of vitamin D on skeletal muscle function and cellular signaling," Journal of Steroid Biochemistry and Molecular Biology, vol. 125, no. 3-5, pp. 159-168, 2011.

[75] K. E. Broe, T. C. Chen, J. Weinberg, H. A. Bischoff-Ferrari, M. F. Holick, and D. P. Kiel, "A higher dose of vitamin D reduces the risk of falls in nursing home residents: a randomized, multipledose study," Journal of the American Geriatrics Society, vol. 55, no. 2, pp. 234-239, 2007.

[76] M. H. Murad, K. B. Elamin, N. O. Abu Elnour et al., "The effect of vitamin D on falls: a systematic review and meta-analysis," Journal of Clinical Endocrinology and Metabolism, vol. 96, no. 10, pp. 2997-3006, 2011.

[77] P. Gerdhem, K. A. M. Ringsberg, K. J. Obrant, and K. Akesson, "Association between 25-hydroxy vitamin D levels, physical activity, muscle strength and fractures in the prospective population-based OPRA Study of Elderly Women," Osteoporosis International, vol. 16, no. 11, pp. 1425-1431, 2005.

[78] H. A. Bischoff-Ferrari, T. Dietrich, E. J. Orav et al., "Higher 25-hydroxyvitamin D concentrations are associated with better lower-extremity function in both active and inactive persons aged $\geq 60$ y," American Journal of Clinical Nutrition, vol. 80, no. 3, pp. 752-758, 2004.

[79] C. Annweiler, A.-M. Schott, G. Berrut, B. Fantino, and O. Beauchet, "Vitamin D-related changes in physical performance: a systematic review," Journal of Nutrition, Health and Aging, vol. 13, no. 10, pp. 893-898, 2009.

[80] L. Ceglia and S. S. Harris, "Vitamin D and its role in skeletal muscle," Calcified Tissue International, vol. 92, no. 2, pp. 151-162, 2013.

[81] D. K. Houston, M. Cesari, L. Ferrucci et al., "Association between vitamin $\mathrm{D}$ status and physical performance: the inCHIANTI study," Journals of Gerontology A Biological Sciences and Medical Sciences, vol. 62, no. 4, pp. 440-446, 2007.

[82] M. Haroon and O. FitzGerald, "Vitamin D deficiency: subclinical and clinical consequences on musculoskeletal health," Current Rheumatology Reports, vol. 14, no. 3, pp. 286-293, 2012. 
[83] H. A. Bischoff, M. Borchers, F. Gudat et al., "In situ detection of 1,25-dihydroxyvitamin $\mathrm{D}_{3}$ receptor in human skeletal muscle tissue," Histochemical Journal, vol. 33, no. 1, pp. 19-24, 2001.

[84] O. H. Sorensen, L. B. Lund Bi., and B. Saltin, "Myopathy in bone loss of ageing: improvement by treatment with $1 \alpha-$ hydroxycholecalciferol and calcium," Clinical Science, vol. 56, no. 2, pp. 157-161, 1979.

[85] R. Boland, "Role of vitamin D in skeletal muscle function," Endocrine Reviews, vol. 7, no. 4, pp. 434-448, 1986.

[86] L. Ceglia, "Vitamin D and its role in skeletal muscle," Current Opinion in Clinical Nutrition and Metabolic Care, vol. 12, no. 6, pp. 628-633, 2009.

[87] C. M. Girgis, R. J. Clifton-Bligh, N. Mokbel, K. Cheng, and J. E. Gunton, "Vitamin D signaling regulates proliferation, differentiation and myotube size in $\mathrm{C}_{2} \mathrm{C}_{12}$ skeletal muscle cells," Endocrinology, vol. 155, no. 2, pp. 347-357, 2014.

[88] L. A. Garcia, K. K. King, M. G. Ferrini, K. C. Norris, and J. N. Artaza, "1,25(OH) $)_{2}$ vitamin $\mathrm{D}_{3}$ stimulates myogenic differentiation by inhibiting cell proliferation and modulating the expression of promyogenic growth factors and myostatin in $\mathrm{C}_{2} \mathrm{C}_{12}$ skeletal muscle cells," Endocrinology, vol. 152, no. 8, pp. 2976-2986, 2011.

[89] Y. Wang and H. F. DeLuca, "Is the vitamin D receptor found in muscle?” Endocrinology, vol. 152, no. 2, pp. 354-363, 2011.

[90] R. Gupta, U. Sharma, N. Gupta et al., "Effect of cholecalciferol and calcium supplementation on muscle strength and energy metabolism in vitamin D-deficient Asian Indians: a randomized, controlled trial," Clinical Endocrinology, vol. 73, no. 4, pp. 445-451, 2010.

[91] M. Pfeifer, B. Begerow, H. W. Minne, K. Suppan, A. FahrleitnerPammer, and H. Dobnig, "Effects of a long-term vitamin $\mathrm{D}$ and calcium supplementation on falls and parameters of muscle function in community-dwelling older individuals," Osteoporosis International, vol. 20, no. 2, pp. 315-322, 2009.

[92] L. D. Moreira-Pfrimer, M. A. C. Pedrosa, L. Teixeira, and M. Lazaretti-Castro, "Treatment of vitamin D deficiency increases lower limb muscle strength in institutionalized older people independently of regular physical activity: a randomized double-blind controlled trial," Annals of Nutrition and Metabolism, vol. 54, no. 4, pp. 291-300, 2009.

[93] S. Kukuljan, C. A. Nowson, K. Sanders, and R. M. Daly, "Effects of resistance exercise and fortified milk on skeletal muscle mass, muscle size, and functional performance in middle-aged and older men: an 18-mo randomized controlled trial," Journal of Applied Physiology, vol. 107, no. 6, pp. 1864-1873, 2009.

[94] P. Lips, N. Binkley, M. Pfeifer et al., "Once-weekly dose of 8400 IU vitamin $\mathrm{D}_{3}$ compared with placebo: effects on neuromuscular function and tolerability in older adults with vitamin D insufficiency," American Journal of Clinical Nutrition, vol. 91, no. 4, pp. 985-991, 2010.

[95] A. M. Kenny, B. Biskup, B. Robbins, G. Marcella, and J. A. Burleson, "Effects of vitamin D supplementation on strength, physical function, and health perception in older, communitydwelling men," Journal of the American Geriatrics Society, vol. 51, no. 12, pp. 1762-1767, 2003.

[96] H. A. Bischoff-Ferrari, B. Dawson-Hughes, H. B. Staehelin et al., "Fall prevention with supplemental and active forms of vitamin D: a meta-analysis of randomised controlled trials," British Medical Journal, vol. 339, Article ID b3692, 2009.

[97] K. M. Sanders, A. L. Stuart, E. J. Williamson et al., "Annual highdose oral vitamin $\mathrm{D}$ and falls and fractures in older women: a randomized controlled trial," Journal of the American Medical Association, vol. 303, no. 18, pp. 1815-1822, 2010.

[98] K. V. Knutsen, A. A. Madar, P. Lagerløv et al., "Does vitamin $\mathrm{D}$ improve muscle strength in adults? A randomized, doubleblind, placebo-controlled trial among ethnic minorities in Norway," Journal of Clinical Endocrinology and Metabolism, vol. 99, no. 1, pp. 194-202, 2014.

[99] R. Goswami, M. Vatsa, V. Sreenivas et al., "Skeletal muscle strength in young Asian Indian females after vitamin D and calcium supplementation: a double-blind randomized controlled clinical trial," Journal of Clinical Endocrinology and Metabolism, vol. 97, no. 12, pp. 4709-4716, 2012.

[100] C. Cipriani, E. Romagnoli, V. Carnevale et al., "Effect of a single oral dose of $600,000 \mathrm{IU}$ of cholecalciferol on muscle strength: a study in young women," Journal of Endocrinological Investigation, vol. 36, no. 11, pp. 1051-1056, 2013.

[101] N. K. Latham, C. S. Anderson, A. Lee, D. A. Bennett, A. Moseley, and I. D. Cameron, "A randomized, controlled trial of quadriceps resistance exercise and vitamin D in frail older people: the frailty interventions trial in elderly subjects (FITNESS)," Journal of the American Geriatrics Society, vol. 51, no. 3, pp. 291-299, 2003.

[102] C. Annweiler, A.-M. Schott, G. Berrut, B. Fantino, and O. Beauchet, "Vitamin D-related changes in physical performance: a systematic review," Journal of Nutrition, Health and Aging, vol. 13, no. 10, pp. 893-898, 2009.

[103] G. P. Levin, C. Robinson-Cohen, I. H. de Boer et al., "Genetic variants and associations of 25-hydroxyvitamin D concentrations with major clinical outcomes," Journal of American Medical Association, vol. 308, no. 18, pp. 1898-1905, 2012. 


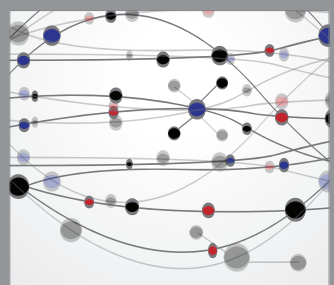

The Scientific World Journal
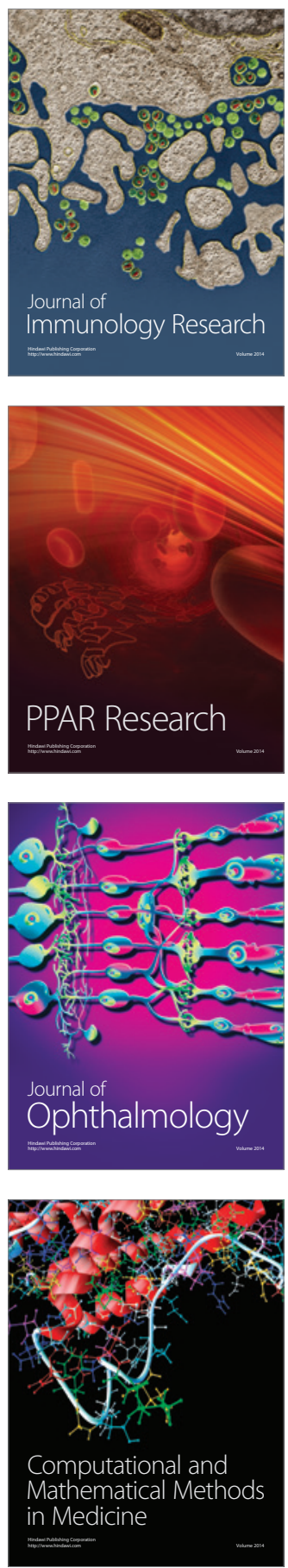

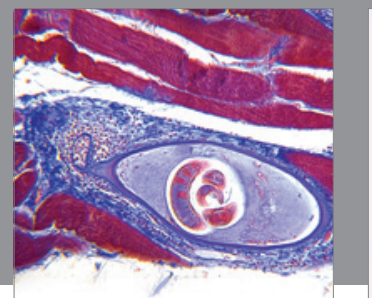

Gastroenterology

Research and Practice
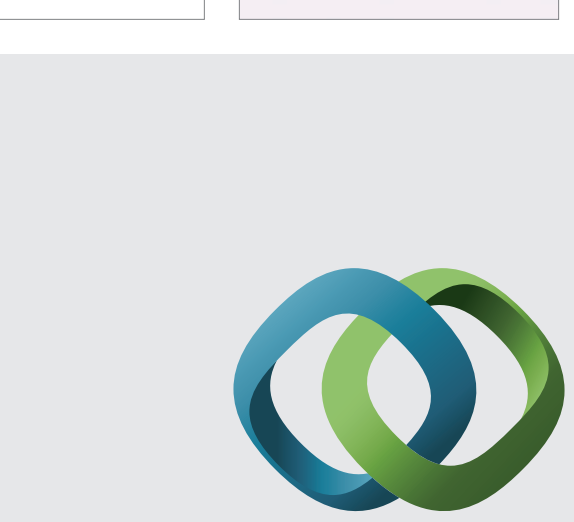

\section{Hindawi}

Submit your manuscripts at

http://www.hindawi.com
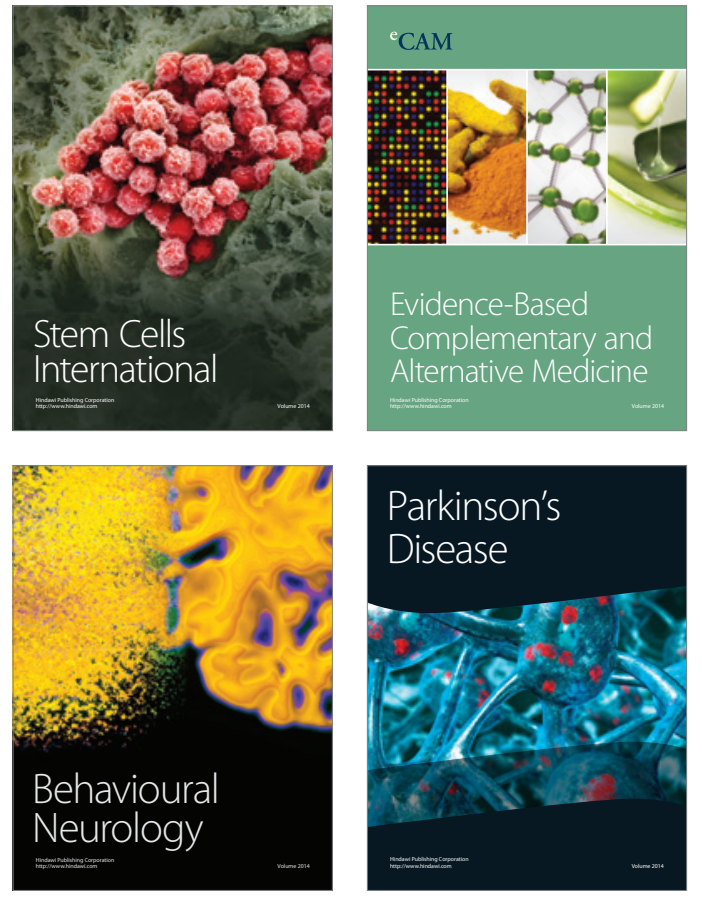
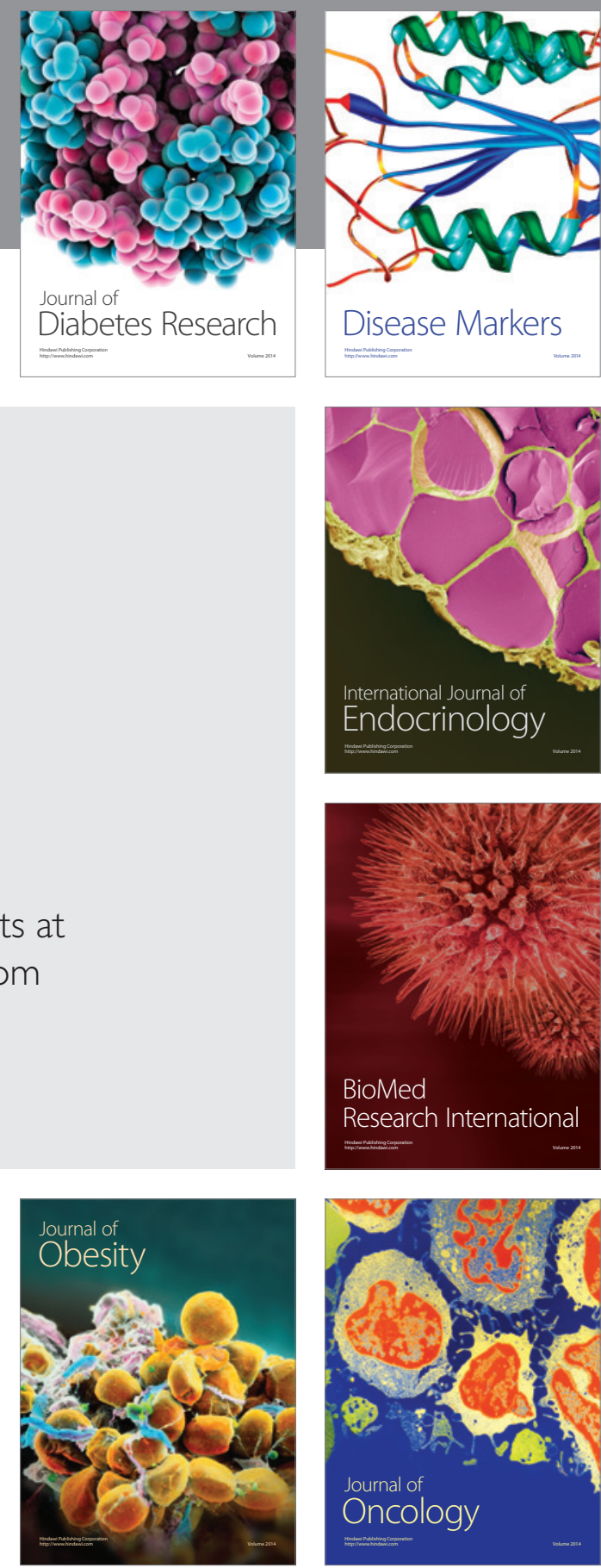

Disease Markers
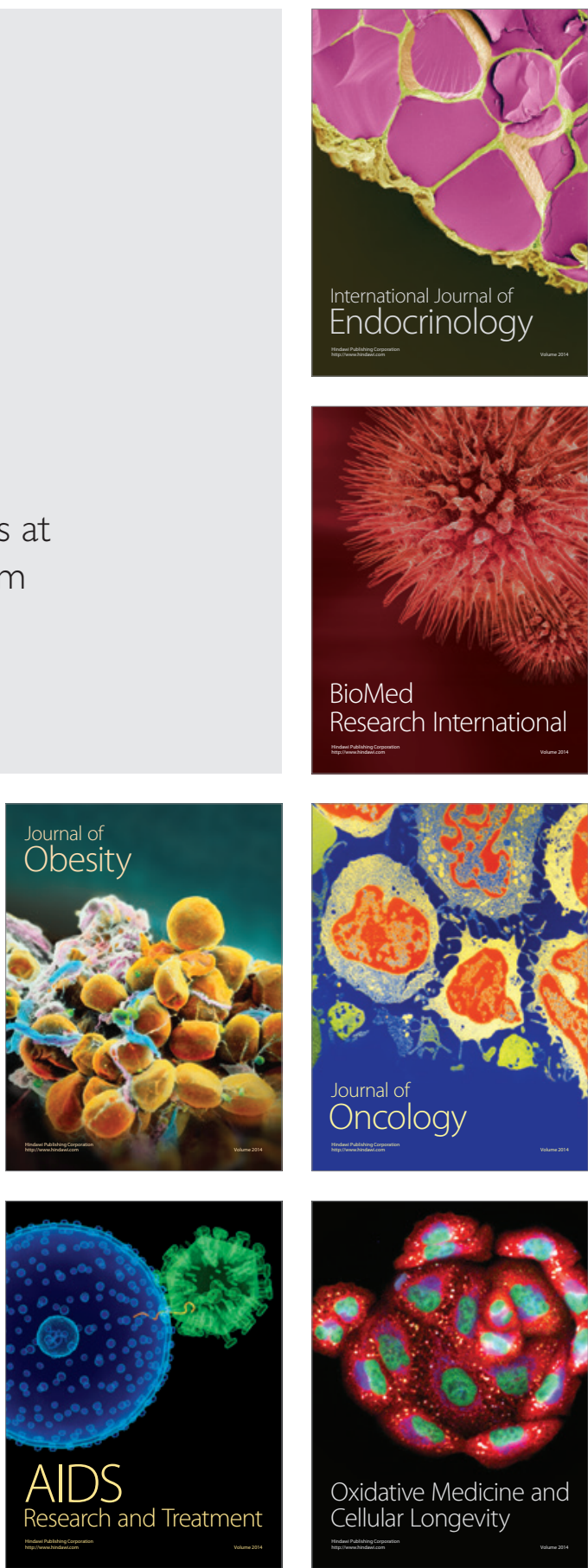